\title{
Water and the environment in southern Africa: A review of the literature since 1990
}

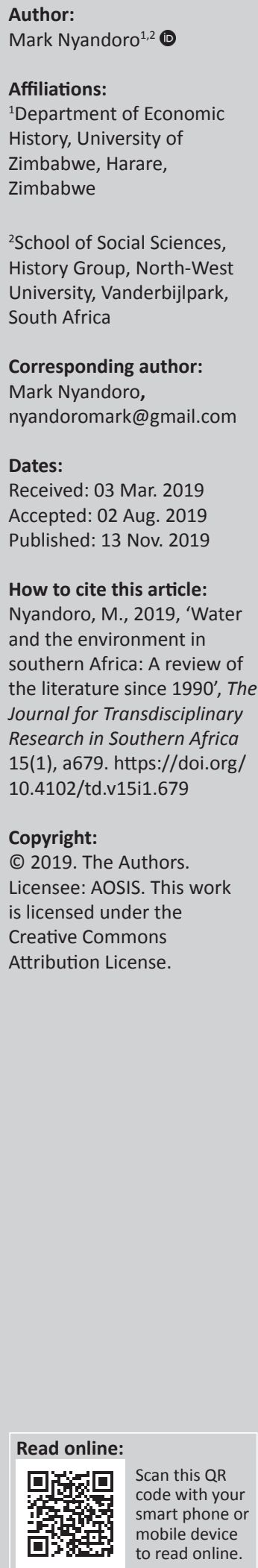

This article is a review of the dominant literature on water issues, water rights and the environment in southern Africa. Being the first in a series of reviews of different regions, it is framed through a survey of national literature that has emerged since the 1990s, with a particular focus on South Africa, Zimbabwe and Botswana. Its central objective and/or purpose is to review select publications in which I foreground significant historiographical tendencies as they relate to my topic on water and the environment. The major tendencies or trends define the content of the article about these countries that form an important part of the SADC region. It traces how water history (a subdivision of environmental history) in southern Africa has developed and evolved, and outlines how scholarly debates have changed over time. To achieve this, I track the major themes of water-history focusing on who produced the works cited, when were they produced, and critically surveying their tenors, themes or intention. What motivated this write-up and assessment of the source material is that several works on this topic have been produced by multiple scholars from diverse academic disciplines: water experts and/or practitioners, ecologists and/or environmentalists, historians, economists, social scientists, hydrologists and policy makers. But not much work has been conducted in the social sciences domain to highlight major water rights and environmental benchmarks from an economic history perspective - a perspective that combines the social and economic analysis of events without disregarding the impact of politics on life and society.

Keywords: Water; water pollution; environment; hydro-politics; rural and urban water; irrigation; agriculture; conservation; water rights; water governance; water historiography; Southern Africa.

\section{Introduction and the southern African water context}

With special reference to South Africa, Zimbabwe and Botswana, this review of southern African literature on water and the environment since the 1990s is essential. It reveals the importance not only of water and the environment as key elements in the development of these societies, but also the fact that this is a vast subject. Because it is vast, I address only the major topics and themes using the three countries as examples that are reflective of the bigger southern African water and environmental landscape. For readers unfamiliar with scholars and the scholarship on water policy and water history in southern Africa, the review helps to illuminate the major issues or themes of this rich scholarship. It helps readers of water and environmental history as related disciplines in the region to understand better the different thematic approaches and debates about water. Furthermore, it is clear that the region is arid and that scholarship or water literature tends to focus on particular issues - irrigation, water provisioning, water policy history and health within a national framework. However, scholars may need to expand their frame of reference to include water systems and their place in sustainability and economic development ${ }^{1}$ studies. As an economic historian with an interest in how societies are organised, looking at the broad literature on water in the region helps me to understand how societies are ordered around water for livelihoods, sustainable development and economic growth.

A review of the key literature on the subject, premised on clear discussion signposts, illustrates that the 1990s and 2000s generated works based on water delivery and water conservation issues (development and management) that, in the wake of droughts caused by changes in

1 In this essay sustainable development is economic development that is conducted without wantonly depleting natural resources. In a UN Brief for the Global Sustainable Development Report (GSDR), Emas (2015) calls it development that meets the needs of the present, without compromising the ability of future generations to meet their own needs. The GSDR is a United Nations publication aiming to strengthen the science-policy interface at the High Level Political Forum (HLPF) on Sustainable Development. In September 2015, UN Member States adopted the 2030 Agenda for Sustainable Development, which gives the GSDR a role in the follow-up and review of the new Agenda. The 2030 Agenda for Sustainable Development has replaced the New Millennium Development Goals (MDGs). 
climate, attempted to balance water supply and demand for various sectoral interests. Important works that make up this core of the water supply and demand historiography and the historiography on livelihoods in the three specific countries of the Southern African Development Community (SADC) region include those written by Cleophas (1997), Ginster et al. (2010), Manzungu (2004), Musemwa (2010), Nyandoro (2018), Steenkamp (1991), Swatuk and Rahm (2004), Tempelhoff et al. (2009), Tlou and Campbell (1997) and Turton (1999a, 1999b). In these and others, water, as a natural resource, is portrayed as critically essential to many sectors of the economy such as agriculture (irrigation), industry, mining, livestock, wildlife, trade, transport, tourism, energy or hydroelectric power (HEP) generation and household use. It is also a key element in water supply and sanitation (WSS) provision. The works illustrate that diverse water discourses and historiographies have emerged in the region, with changing interpretations over time. In the literature on urban areas, hydro-politics frequently centre on water shortages, the impact of polluted water environments and their ramifications on human or public health.

Major debates on the aquatic environment in the region have whetted the appetite of some scholars, but have escaped the attention of others who largely focus on different aspects. Water is diversely portrayed as a basic necessity for all forms of life on earth, a fundamental human right and a vehicle for socio-economic development. Its shortage and contamination, therefore, compromise life, agro-industrial and other activities.

In the historiography of scarcity (Turton 1999a; Turton \& Ohlsson 1999), water shortage is one of the peculiarities of the SADC region. Tempelhoff (2018:1) has aptly observed that 'water has a long history as a notoriously scarce resource in the greater part of southern Africa'. Its shortage is a major cause of local, national and international anxieties. Examining the role of water in light of its scarcity is vital, as it hits at the heart of a number of growth issues. The function and availability of water in the development of southern Africa are taken to be given, and the scarcity of water is an overlooked but fiercely contested issue requiring further study and explication. This was one major justification for the construction of large dams, which, in multiple ways, were linked to the rainwater harvesting technologies that have evolved in the region. Wide-ranging debates on water by Attwell (1970:189-196), Ginster et al. (2010:1-24), Isaacman and Isaacman (2013:1-324) and Nyandoro (2014), for example, focus not only on the constructive and positive elements of this commodity, but also on the role of these large impoundments (dams or reservoirs) and their positive and baneful impacts on the environment and ecosystems. Less intensive research has, however, been conducted regarding the significant increase in the human and economic impacts of water disasters that have been witnessed in recent years. Such disasters include the crippling drought that affected the Sahel in Africa from 1972 to 1984 and the sporadic, but sometimes endemic, floods or cyclones ${ }^{2}$ that have afflicted the region between the late 1990s and the turn of the 21st century.

This article specifically reviews three regional cases, focusing on the literature of key regional scholars on water such as Ginster et al. (2010), Nyandoro (2019a), Tempelhoff et al. (2009), Turton (1999a), and so on. In the process, the implications for water resource scarcity of decrepit water infrastructure in these countries are noted as some of the major trends in these scholars' writing. However, the attempt, as the literature demonstrates, is not to assume that water supply, development and management are homogeneous processes in these three countries. The homogeneity of water discourse in these regional countries, while apparent in certain instances, cannot be said to outweigh its heterogeneity. There are, thus, decisive similarities and differences in the perceptions of the delivery of water and how water governance is ordered and implemented in each of these respective countries as portrayed in the literature. Broadly, the way water supply and management are organised in many parts of the world ranges from traditional co-operative models to socially involved and government-supported institutional systems. However, southern African models, while they conform to all these styles, are predominantly state-initiated as some states perceive water as a public good or public commodity over which they have a social responsibility. In this vein, South Africa and its two regional neighbours subscribed to the principles of the 1992 Dublin Statement, which emerged from the International Conference on Water and Sustainable Development of that year. This forum was to influence water demand and water resources management historiography for more than two decades afterwards.

The Dublin Conference, among other things, emphasised the commodification of water as an economic good, and in the decade after 1992 was to inform South Africa's water

2.A rare three-day spell of Cyclone Idai-related rain in March 2019 was a tragic disaster that ranks as one of the worst natural-disasters ever experienced in the southern African region in many years. The cyclone, comprising heavy and violent winds, rain and mudslides had devastating consequences for Zimbabwe's Chimanimani and Chipinge areas in Manicaland Province, Mozambique (especially Beira) and Malawi. These countries were still counting their losses in both human and material terms. People died from serious storms and floods. Some are still missing (their bodies may never be found), and infrastructure (houses, roads, bridges, schools, clinics, servicecentres, fields, irrigation equipment etc) has been destroyed. The magnitude of disaster displacement and how to manage the risk and impact for the affected peoples/communities is beyond imagination. Agricultural fields, livestock (mainly peoples/com mats) besives and livestock (mainly cattle and goats), beehives and other sources of livelinood were washed away by the floods or were blown away by the severe or ravaging storms. In trying to conceptualise how tragic it was, official statistics may be an under-estimation of (victims), infrastructure destruction and the impact not only on victims' remaining relative but also the country. Its impact was particularly bad for people living in poverty (the very poor). It was an emergency requiring huge humanitarian assistance; hence it prompted donations to come through the Red Cross, the United Nations Children's Fund (UNICEF), the World Health Organization (WHO), Oxfam, the International Rescue Committee (IRC) and other local and international humanitarian organisations. In a statement, the Zimbabwe Agriculture minister, Perrance Shiri, said the situation and the damaged infrastructure and facilities 'resemble[d] an aftermath of a full-scale war, whereby bridges [were washed away] and the infrastructure [was] destroyed to the extent we did not expect'. The situation also forced a renowned international academic research institution, the African Studies Association (ASA) to issue a statement on Cyclone Idai: 'We at the African Studies Association (ASA), to issue a statement on Cyclone Idai: 'We at the African Studies Association are full of sorrow over the massive human toll exacted by Cyclone Idai on the peoples of Mozambique, Malawi, and Zimbabwe. As we write 750 people across southern Africa have been reported dead; more than a half million people have been displaced by flooding and landslides; and 110,000 people are living in reception camps. Mozambique's fourth-largest city, Beira, is largely destroyed Relief efforts coordinated by local and international groups are beginning to have a positive effect, but there are huge challenges ahead'. 
governance structures and their alignment with international trends (Tempelhoff 2018:445; see also Tempelhoff 2005:123146). The alignment was carried out by its state agency, the Department of Water Affairs and Forestry (DWAF), previously known as the Department of Water Affairs (DWA). As per the Dublin principles, the vulnerability of fresh water as a finite and vulnerable source, the principle of integrated water resources management (IWRM), ${ }^{3}$ and better understanding of the role of women in the procurement and management of domestic water were also emphasised by states. In Zimbabwe, the state adopted the IWRM paradigm and formulated new legislation (the Water Act and the Zimbabwe National Water Authority Act or ZINWA Act of 1998 ) or water policy frameworks that encouraged the participation of all stakeholders, especially users of water in the decision-making process through consultative water catchment management structures (Pazvakavambwa 2002). These state water-sector reforms were prompted by calls from both international organisations and forces within the country. In Botswana, while the state had a role to play in water delivery and management through state or public water enterprises such as the Water Utilities Corporation (WUC) of 1970, it also decentralised water services by giving autonomous power to non-governmental organisations (NGOs), water user associations and private institutions. Such an approach strengthened the government of Botswana's central theme of good governance for water preservation and utilisation whose merits were the enhancement of water policy formulation, legislation and the creation of democratic space in the country (Nyandoro 2018:102-103). The role of the state in ensuring that water was both a social and economic good and its role in stimulating stakeholder participation in the water sector then came to dominate the works by Kujinga and Manzungu (2004:67-91), Manzungu (2001), Manzungu and Dzingirai (2012:85-109), Nyandoro (2018), Swatuk and Rahm (2004) and Tempelhoff (2018).

Several works that have emerged mainly since the 1990s make up the dominant and, to a certain extent, the marginal southern African historiographies on water and the environment. The dominant narratives include water shortages, water contamination or pollution and their impact on the environment. With reference to the three selected countries of southern Africa, the review essay contextualises water and environmental management

\footnotetext{
3.IWRM is a framework designed to improve the management of water resource based on four key principles adopted at the January 1992 Dublin International Conference on Water and the Environment (ICWE) and the Rio de Janeiro Summit Conference on Water and the Environment (ICWE) and the Rio de Janeiro Summit
on Sustainable Development. These principles state that: (1) fresh water is a finite and vulnerable resource essential to sustain life, development, and the environment (2) water development and management should be based on a participatory approach, involving users, planners, and policy-makers at all levels; (3) women play a central part in the provision, management, and safeguarding of water; and (4) water has an economic value in all its competing uses and should be recognised as an economic good. IWRM is, therefore, not a prescriptive description of how wate should be managed, but it is a broad framework in which decision makers can collaboratively decide the goals of water-management and co-ordinate the use of different instruments to achieve them. Given that each country differs in terms of different instruments to achieve them. Given that each country differs in terms of history, socio-economic conditions, cultural and political context, and environmental characteristics, there is no single blueprint for IWRM and it can be adapted to resolve the problems faced in each local context. The IWRM concept is the flagship project of supranational global water bodies or institutions such as the Global Wate Partnership (GWP) and the World Water Council (WWC). For detail, see GWP (2011); ICWE (1992); Lenton and Muller (2009); Pahl-Wostl, Jeffrey and Sendzimi (2011); White (2013).
}

narratives within multidisciplinary or interdisciplinary studies of the region. Scholarly discourse on hydro-politics and the general aquatic environment covers a broad range of different, albeit connected, topical and thematic questions that are not exhaustive (cannot be exhausted) for a brief regional review like this one. In the period after the 1990s, it is true that the hydro-political and historical landscape of the three countries under discussion has been shaped, in a major way, by discussions of water, its scarcity, quantity and the impact of a polluted aquatic environment on life or livelihoods, while other aspects that are subsumed under pollution, such as water quality, have not necessarily been denigrated to a marginal or secondary position, but have been covered by a few scholars (Nyandoro 2019a). By contrast, water historiography in the preceding decades was dominated by agro-irrigation studies by scholars, such as Roder (1965), who emphasised the colonial white fascination with water largely for the development of the European commercial agricultural sector and not the peasant smallholder sector. Notwithstanding this unsurpassed colonial fascination with the water and water resources development paradigm of the 1920s-1960s, there was a clear paradigm shift particularly from the 1990s onwards by major regional scholars such as Musemwa (2010, 2014), Tempelhoff (2009) and Nyandoro (2011:154-174). This shift entailed encouraging pristine aquatic environments (interacting systems of resources such as water and biota) as major sources of water and food to millions of people across the region. The chief proponents of this recent scholarship emphasising clean water that is free of disease in line with global and regional $\mathrm{WASH}^{4}$ considerations, although challengeable in certain respects, have therefore been responsible for pioneering the existing and domineering transdisciplinary water research landscape that is likely to transcend the new millennium.

This multidisciplinary southern African water and environmental historiography or water history scholarship with a trajectory dating back to the 1990s, and which is informed by topical and thematic perspectives of a wideranging nature, is polarised between works that advance certain disciplinary aspects and those that marginalise such aspects. It is, in this regard, important to recognise polarisation depending on who influences the dominant water sector paradigms and their associated shifts at given periods in time. The contending parties in this are the state, academics and other institutional bases. Despite the problems wrought by aridity, water historiography seems to have been static in the pre-colonial and colonial periods.

However, the situation has, since the end of the 20th century, increasingly assumed a more progressive and proactive dynamism than hitherto known. A major argument for this historiographical article relates to how the contending scholars have addressed issues of aridity, limited water 4.A detailed discussion of water, sanitation and hygiene (WASH) appears later in
this review under the sub-section: 'Southern Africa: Water and its Shifting Historiographical Terrain' 
resources and the availability of potential sites for water resources development. Arguments by Ginster et al. (2010), Cleophas (1997) and Swatuk and Rahm (2004) are impelled by the desire to understand how different water authorities coped with the difficulties they faced in managing scarce water resources, and how their responses to the difficulties have influenced water policy formulation. Important lessons for Africa can be drawn from countries within southern Africa such as Botswana and others that are emerging from a colonial structure with no major investment in water (Nyandoro 2013, 2018). This review of the extensive local and international literature that exists on water and its environmental context in southern Africa contends that access to water and its control are central to economic transformation as well as the improvement of southern African peoples' standards of living. In this regard, the importance of water (as reflected through the major topics and themes) and its far-reaching social and economic implications on the selected developing countries of the region is a critical issue for scholars who have made pertinent observations leading to the building of a southern African historiography on water.

It can be argued that regional and global water history has over time been subjected to discussions of a sundry nature. The major debates about water and the environment in southern Africa, similar to other regions of the world, as noted, pit the wits of economic historians, environmental historians, ecologists, social scientists, engineers, hydrologists, economists, rural and urban planners, international agencies, state policy-makers and civic society, to name but a few. Debates on water, among other things, have characteristically looked at questions about water politics and conflicts, water and environmentalism, water as a social or economic good, water service delivery, transboundary water and legislation or policy, water and sustainable economic development, and water and food security. The works cited and the time they were produced illuminate the major issues or themes contained in the rich southern African scholarship on water. This historiography traces how water history in southern Africa developed and evolved across time and space to its contemporary state in each of the three countries.

\section{Contemporary water historiography and its genesis in southern Africa A fascination with water - the Rhodesian or Zimbabwean scenario}

The origins of contemporary regional water history narratives in southern Africa can be traced to the post-independence era in South Africa, Zimbabwe and Botswana. For the colonial period, Euro-centric approaches tended to dominate Afrocentric water, land and natural resource discourses because issues of rights around the two resources were not only inseparable, but also vital and contentious in both the colonial and post-colonial periods. In the years prior to independence, such literature mainly showing a racial segregationist slant by white Rhodesians (white people who lived in modern-day Zimbabwe) was not uncommon, as portrayed by Palmer (1977) in his recent work, Land and Racial Domination in Rhodesia. Scholarly work by Palmer, among others, analyses racial legislation such as the Land Apportionment Act (LAA) of $1930 / 31$ - an Act that certainly stirred up antagonism and conflict because of the displacement and dispossession it engendered - also because it tended to be prescriptive and enforced top-down, not bottom-up, strategies discussed in the last segment of this essay.

Under the terms of the $L A A$, the rights of the Africans to landownership and, to a major extent, water anywhere in the colony, were rescinded (Moyana 1984:58). Nonetheless, as reflected in the Morris Carter Commission or the Lands Commission of 1925, the Rhodesian settlers had argued against a complete segregation of Africans and Europeans simply because they knew that the Europeans were dependent on the agricultural labour provided by the Africans residing on European-controlled land (Moyana 1984:58; Nyandoro 2012:306). Invariably, agriculture depended on sufficient and efficient water supply. Because agriculture has been declared the mainstay of the country's economy, Rhodesian historiography during the 1920s and after the 1960s thus portrays a clear white obsession with water. This has been testified by the works of Roder (1965), which demonstrate that government intervention in smallholder irrigation agriculture began in the late 1920s alongside peasant farmerestablished irrigation schemes of the early 20th century. This obsession with water did not wane in the 1960s especially after the 1965 Unilateral Declaration of Independence (UDI), but continued in the 2000s, as illustrated through the works of David Hughes (2010) and Joost Fontein (2017). Hughes emphasises the theme of belonging using white identity and water, while Fontein focuses on the grandiose Lake Kariba which was important for the provision or supply of water, electricity (light) and power.

The book by Hughes is a focused commentary on Zimbabwean whiteness. Divided into two parts, the first part of the book focuses on the Zambezi and the imaginaries constructed around the river and the Kariba Dam. The second and last part focuses on the farms near the town of Marondera in Mashonaland East Province, situated east of the capital Harare. In Whiteness in Zimbabwe, Hughes (2010) offers a fascinating analysis of how white farmers constructed and understood their role in the country before, during and after the contentious agrarian reforms of 2000 . The book - a critical exposition of the connections between the white group's environmental conservation and its 'racial' identity - is an ethnographical study epitomising colonisation processes or procedure. Hughes, clearly influenced by a distinguished novelist, Coetzee's (1988) White Writing, alludes to the 'dream topographies' of the country (Zimbabwe) that white people have created through a combination of imagination and engineering. Quite contentiously, he argues:

To feel at home, 'Euro-Africans', these 'children of the glaciers' accustomed to Wordsworthian landscapes [Britons and other 
northern Europeans who appreciated a well-watered topography], transformed the African vistas: Zimbabwe had no lakes, so they built them. (pp. 5, 29, 30, 86, 129)

He thus describes the massive project that spawned the Kariba Dam and its lake. With an incisive exegesis of scientific and fictional works featuring the lake, he shows through literature and photography how this artificial body of water has become, in European folklore (mythology), the myth of the African wilderness. Dams of this nature explain and show how the white settler government of Rhodesia, just like their South African counterparts, shouldered the responsibility of ensuring that adequate water storage facilities and the necessary infrastructure were created to supply sufficient water to farming operations, industrial activities in the mining sector and the growing conurbations. Hughes further describes how, after Zimbabwe's independence in 1980, investing in major farm projects, such as irrigation was also an investment in identity, giving the farmers a legitimate role in the 'new' country while they continued their drive to transform its space through dam construction and installation of water infrastructure.

In the historiography on Zimbabwe water, this white obsession with the commodity (water) - an obsession that dominated most colonial and post-colonial Euro-centric writings - can be summed up in the words of one Rhodesian colonial official, H.R. Hack. Contributing to debate in parliament on the introduction of Estate agriculture, the formation of the Agricultural Development Authority $(\mathrm{ADA})^{5}$ in Zimbabwe and its functions, powers and organisation, H.R. Hack, the Chief Planning Officer of the Sabi-Limpopo Authority (SLA), emphasised the importance of understanding the role of water in the economy. The SLA Act [Chapter 156] 1975 governed, with the approval of the Minister of Energy and Water Resources Development, the construction, establishment, acquisition, maintenance and operation of dams, canals and hydroelectric power (HEP) stations. Hack presented and developed his argument on agriculture and water by saying:

In the Phillips Report [1962] $]^{6}$ - and several other reports that have been written on agriculture - it is stated emphatically that agriculture will continue to be our main industry for a considerable time to come by virtue of the [three basic elements] resources of land, water and labour [also capital and markets] which we have ...7

As far as water is concerned, he believed Rhodesia was well endowed with this resource. However, the big question was '... where and how to harness these [water] resources to best advantage, and having harnessed them, how best to utilize them?' Continuing his argument, he insisted that, '... water harnessed now will double, treble and quadruple in value

5.The Agricultural Development Authority (ADA) was renamed the Agricultural and Rural Development Authority (ARDA) after independence in 1980.

6.See also Roder (1964).

7.National Archives of Zimbabwe Records Centre (hereafter) NAZ (RC), ARDA, Box 348063, Location R24.9.6.4F, File: ADA/POL/1 Part 1: Formation of ADA, ADA's Extract of Parliamentary Debates, s.a., 1-2. over the next twenty-five years'. Hence, any commodity that had the capacity to do that was a 'sound investment by anybody's standards'. Therefore, according to Hack, who had been sent by $\mathrm{CONEX}^{8}$ to the United States to do a specialised course on farm planning and land utilisation:

If we set up an ADA, hit the single weakest point in agriculture assuming agriculture is our biggest resource - what is the single weakest point in agriculture - water - and do it exactly within the frame of our Act [SLA Act]. Hit the water, harness the water for a purpose, project the purpose, finance it with sufficient capital. [That is the trick] (NAZ, Formation of ADA, ADA's Extract of Parliamentary Debates:6-7). ${ }^{9}$

Water resource development therefore occupied an important place in the white Rhodesians' efforts to develop not only agriculture but also the entire national economy. The same applied to South Africa as revealed in the literature by prominent water historians.

\section{Racial division and water development in South Africa}

The following brief colonial water historiography of South Africa and Botswana demonstrates race history at one of its peak forms in southern Africa. Racial division emerged in South Africa (Rhodesia's southern neighbour) as early as the 1600s because of Dutch settlement. It began with the Europeans maintaining segregation and hierarchy between themselves, their labourers or 'slaves', most of whom were from Asia, and local African populations. Segregation became more apparent than ever before when Cape Town (commonly referred to as the 'Mother City' in the Republic) was founded by the Dutch East India Company or the Vereenigde Oostindische Compagnie (VOC) in 1652 as a refreshment outpost. The outpost was intended to supply VOC ships on their way to Asia with fresh fruits, vegetables, meat and to enable sailors wearied by the sea to recuperate. The location of the town in the Table Bay area was influenced by the availability of fresh water, which was difficult to find in other parts of the Cape. This means that although Cape Town remained dry, it was primarily founded (prior to the formation of any formal water department) because of its favourable environment and the copious water supplies which flowed from streams and aquifers nestled in the Table Mountain system (Tempelhoff 2018:1).

In South Africa's water historiography, it was not until after the formation of the Union of South Africa in 1910 that the government Department of Irrigation responsible for water governance in terms of the Irrigation and Conservation of Water Act, No. 8 of 1912 was launched. In 1956, when the Water Act, No. 54 was passed, that the name of the department changed

8.The Department of Conservation and Extension (CONEX) was responsible for providing extension services in the white commercial farming sector in Rhodesia.

9.National Archives of Zimbabwe Records Centre (hereafter) NAZ (RC), ARDA, Box 348063, Location R24.9.6.4F, File: ADA/POL/1 Part 1: Formation of ADA, ADA's Extract of Parlian R24.9.6.4F, Fil: ADA/POL/1 Part 1: Formation of ADA, ADA's Extract of Parliamentary Debates, s.a., 6-7. See also Government of Rhodesia, SabiLimpopo Authority Act [Chapter 156], Salisbury, Government Printers, 1975; NAZ (RC), ARDA, Box 348063, Location R24.9.6.4F, File: ADA/POL/1 Part 1. Formation of ADA, Agricultural Development Authority Act/Sabi-Limpopo Authority Act', G.B. Thorpe for Secretary for Agriculture to Controller, Agricultural Development Authority, Causeway, Salisbury, 1 December, 1977. 
to the Department of Water Affairs or DWA in short (Tempelhoff 2017:189). One of the works of a prominent southern African water historian, Tempelhoff (2017:189), has portrayed the new legislation as marking the beginning of a new era in South Africa's water governance because the focus of the department shifted from irrigation infrastructure and bulk water governance responsibilities to making an important contribution to the country's social and economic development. The priorities of the day included the need for more comprehensive water infrastructure for industrial development; meeting the greater demand for water in the country's rapidly growing urban areas; and taking steps against the increasing threat of water pollution (Tempelhoff 2017:189). However, most pre- and apartheid literature is silent about the lack of equitable or fair distribution of water. In this respect, Tempelhoff (2017:189) is an exception by observing that the Department of Irrigation, in terms of the Water Act of 1956, responded to the policy of separate development (apartheid), but at the same time took a deeper and long-term view of the development of water infrastructure to be of value for the country and its people, beyond the shorter temporal view of the political leaders of the day. The first phase of apartheid (1948-1960) was therefore notable for the initial emergence of significant opposition among the country's indigenous African people to the white minority government's segregationist policies, but their struggle was subdued. It is clear from the literature that this phase came to an end at a time (after the 1960s) when the rest of Africa was engaged in rapid decolonisation and South Africa became politically ostracised in the international arena until full democracy was achieved in 1994. Despite having no equity in the water sector in the apartheid era, what is apparent in the literature is that the emergent or nascent hydraulic mission of industrialisation promoted unsurpassed development that was destined to have a marked effect on South Africa's status as a modern industrial state on the African continent (Tempelhoff 2017:189).

Debates on the hydraulic mission are behind the emergence of a new and unique historiography on water studies. It is important to note that at the University of London School of Oriental and African Studies (SOAS) in 1999, South Africa featured prominently in talks and research on the hydraulic mission (Tempelhoff 2018). The prominent South African political scientist and water expert, Anthony Turton, who had close ties at the time with SOAS, was instrumental in transferring (based on his works in the 1960s and 1970s) a number of current theoretical terms, such as hydro-politics and hydraulic mission, into the political and governance discourse on African water. Turton concentrated extensively on theories of water politics (Turton 1999b, 1999c). In much of his works, the theoretical underpinnings of the hydraulic mission were present (Turton 2000, 2001; Turton \& Warner 2002). The hydraulic mission formed part of a comprehensive theoretical reference framework in which he focused on hydro-politics and transboundary water resource governance, to fit in with the discourse on water governance in South Africa from the advent of European colonialism in the 17th century to date (Turton 1999b). Regional water bodies play a vital role in transboundary water management and in the development of sustainable water resources. Apart from Turton's statements about the 1960s and 1970s, when the state was said to take a more assertive stand on water control and management (Turton, Patrick \& Rascher 2008:324), Tempelhoff (2018) argues that there has thus far not been a sensible historical categorisation of the evolution of South Africa's hydraulic mission in the 20th century. This therefore influenced him in his 2018 book to work towards a reasonable understanding of the comprehensive evolution of the hydraulic mission as it evolved in the South African state (Tempelhoff 2018). Thus Tempelhoff, like Turton, has, to a large extent, influenced perception of water in South Africa and the region.

In contrast to the early pieces of legislation of 1912 and 1956 already alluded to, and apartheid historical narratives that had become official history since 1948, the changing interpretations of water and environmental discourse over time are attested to by the most recently introduced legislative measures like the Water Services Act, No. 109 of 1997 (Republic of South Africa [RSA] 1997) and the National Water Act, No. 36 of 1998 (RSA 1998; Tempelhoff 2017:190). Both were passed after South Africa's transition in 1994 to a multiracial democracy (DWAF 2006; Tempelhoff 2017:190-191). A major discernible change, though, was that the content and intent of the new acts, as shown in the literature, were significantly different from all previous (or colonial) water legislation in that the prime principles were now equity (fairness and beneficiation) for all water users and the need for the government to act as custodian of the resource on behalf of all the country's people (Tempelhoff 2017:191). The result was the emergence of a clearly defined social hydraulic mission. At its core and over the longer term, the new water legislation then introduced the basic principle of balancing resource use with the counterpoint of resource protection hitherto or previously unknown. There were preliminary indications of a move towards sustainable development, but not in itself a sustainable practice (Tempelhoff 2017:191). A notable feature of South Africa's water legislation (or emerging legislative historiography), however, has been its consistency as exemplified by the fact that in the course of the 20th century only four primary pieces of legislation relating to water governance were passed by parliament. Each of these pieces of legislation laid down a primary definition of how the water resources of the country would be developed. At the same time, each was representative of a groundbreaking shift in the way the state was governed as well as a shift in the historiography on sustained industrialisation (Tempelhoff 2017:190).

Clearly, the industrialisation drive by the government of South Africa, since the 1940s (including the 1950s development of SASOL ${ }^{10}$ and the late 19th-century mineral

10.Industrialisation continued to progress when Sasol, formerly the South African Coal, Oil and Gas Corporation, started manufacturing synthetic motor fuels Coal, Oil and Gas Corporation, started manufacturing synthetic motor fuels
(petroleum) from coal on a commercial-scale for the domestic, regional and international market from 1955. 
discoveries), to promote growth through mining and industrial manufacturing, positioned the country's water sector to meet the demand for more resources (Tempelhoff 2017:207). It is also clear that politically the old DWA was not an active role player in securing water supplies for urban African townships and the relocated people to so-called separate 'homelands' under apartheid or what the government chose to call Bantustans like the Transkei, Bophuthatswana, Venda and Ciskei (TBVC states) created under the Natives (Abolition of Passes and Coordination of Documents) Act of 1952 and the Promotion of Self-Government Act of 1959. For the most part, the responsibility for water supplies was transferred to local authorities. One consequence was the notably inferior water and sanitation services in the African townships from the 1960s onwards. This issue was addressed in some measure only after the Soweto uprising of 1976, when additional steps were taken at local and regional government level for authorities to improve water supply and sanitation in the urban African townships (Tempelhoff 2003). 'Bantustans' had even entered into 'international' agreements with 'mainland' South Africa on transboundary water management in terms of the Helsinki Rules of 1966 (Tempelhoff 2017:199). On this basis, water history by Tempelhoff is therefore not necessarily just history, but a mirror of the relatively unbiased or impartial assessment of how water was perceived in the past and how it can be perceived now from multidisciplinary angles not only in South Africa but also in the southern African region. These collectively negative and positive water development aspects in South Africa, let alone Rhodesia, in many respects resonate with Botswana's development trajectory in the water sector.

\section{Botswana - Scholarly perceptions of water}

With respect to Botswana, historiography that portrays scholarly perceptions of water in the past and in the present includes works by Cleophas (1997:43-53), Nyandoro (2018:97-111), Steenkamp (1991:292-308) and Tlou and Campbell (1997). Following one of the pioneering works on Botswana water by Peters (1984) in the 1980s, entitled Struggles over water: Struggles over meaning: Cattle, Water and the State in Botswana, the portrayal of the history of struggle over water in an arid terrain has assumed perennial proportions among scholars.

The history illustrates the convergence of minds of state players and the corporate sector over water use and demand by groups of people for a diverse range of purposes (Nyandoro 2018:97-111). For example, water supply services personnel were mostly tasked or preoccupied with providing water within the agricultural sector for livestock (especially cattle, and to a certain extent crops), potable and mining needs in the broad context of a country beset by aridity. Many works on the history of water in Botswana since the 1990s thus emphasise the already affirmed arid status of the country, escalating demand for water and efforts to overcome the challenge of water paucity to achieve growth and sustainable development. Tlou and Campbell (1997) illustrate in their book that the paucity of water supply in Botswana had been inherited from the colonial power, Britain, whose neglect of water development meant that the post-colonial government was constantly and persistently faced by insurmountable water challenges.

Such post-colonial historiographical discourses in southern Africa resonate with the underdevelopment theories propounded by Andre Gunder Frank (1967) for Latin America and Walter Rodney (1973) for Africa. The resonance comes in that Europe siphoned developing world resources for its benefit. In a similar way, the colonial administration's reluctance, because of the costs involved to develop the water sector significantly beyond the precincts of the isolated white enclaves dotted in some parts of the country, was detrimental to Botswana's development. This lack of water development observed by Tlou and Campbell (1997) can be explained in that the colonial enterprise was never meant to benefit the colonised, but to exploit them for the benefit of a small white settler community or European metropole. However, Tlou and Campbell's argument about the colonial neglect of water resource development has generated enormous debate within Botswana colonial water supply and demand historiography as it has been refuted and considered a matter of perception by Steenkamp (1991). ${ }^{11}$ Focusing on colonial Botswana's development policy, Steenkamp rejects the conventional characterisation especially of the 1930s as either one of unremitting neglect or deliberate underdevelopment by providing a totally different perspective regarding the cattle industry. $\mathrm{He}$, for instance, categorically pays tribute to Charles Rey, the Resident Commissioner at the time, for responding to the needs of the country's economy with a comprehensive development strategy focusing on water resources and the revival of the cattle industry. Steenkamp's argument that cattle and water were inextricably linked in colonial Botswana nevertheless cannot be interpreted to mean that there were absolutely no challenges or impediments.

The challenges that afflicted the economy were a result of undeveloped water resources and the fact that water security in the early colonial times was restricted mainly to a reliance on oases (in particular the world's largest inland delta, the Okavango Delta in the middle of the Kalahari Desert, which is Botswana's major freshwater oasis for people and wildlife), boreholes and wells for potable and agricultural water, including water for watering livestock (Nyandoro 2018:97-111; Peters 1984, 1994). This reliance on oases and colonially implemented sources of water, such as boreholes in the face of rising post-colonial demand for water influenced the government of Botswana, which was committed to rectifying water provision and management problems of the past, to facilitate modern water resource development projects. The projects included the establishment of dams (e.g. the Gaborone Dam) and a public water enterprise, the Water Utilities Corporation (WUC), established in 1970, to boost water supply because of water's political, socio-economic 11.See also Nyandoro (2018:97-111). 
and strategic significance for growth. Similar to South Africa, this is therefore a pointer that since Botswana's independence in 1966 as portrayed in the historiography of water supply and demand by Fontein (2008:737-756), Makgala (2012:787-806), Nyandoro (2018:97-111) and Swatuk and Rahm (2004:1357-1364), rising local demand for water in the growing towns (especially the capital city, Gaborone) and surrounding and distant villages strengthened government's resolve to develop national supplies to meet demand in this predominantly desert and water-scarce nation. Hence, although the politics of scarcity and underdevelopment had dominated water historiography in Botswana since the Protectorate times (1885-1965), by the new millennium the state was able to turn the challenges into opportunities despite escalating climate change-induced dryness, its own capacity weaknesses and implementation inefficiencies. For Botswana, this emphasised the point that water insecurity wrought by desert conditions did not always mean lack of development (Nyandoro 2018). Why and how post-colonial state officials played a vital role in securing equitable distribution of water for development against the backdrop of water shortages (the scarcity factor) and funding challenges helps to mark a clear transition from the historiography of scarcity to one not necessarily of abundance, but of efficient and sustainable provision of water. This shift characterises water scholarship throughout the region, more so in the face of endemic droughts besetting southern Africa.

\section{Southern Africa: Water and its shifting historiographical terrain}

Water has had a long history of being a notoriously scarce resource in the greater southern African region, but water historiography has expanded its scope or horizons since the 1990s by embracing vital water sector reforms and initiatives. This includes the amendment or repeal of old water laws that have been replaced by new ones. Since the early 1900s, as a result of constant innovation and modernisation in the fields of water engineering, natural science, management studies and environmental studies, there has been a growing awareness by the state and citizens of the intrinsic interaction between humankind and the environment.

The 1990s and 2000s reflect an era of profound thinking by economic historians writing on water history, geologists, physicists and ecologists (environmentalists) in promoting the idea of a post-Holocene epoch - the Anthropocene. This shift in focus by an increasing number of scholars shows that the way citizens respond to the call for greater societal responsibility is not confined to dealing with greenhouse gaseous and carbon emissions into the atmosphere, but human societies in all parts of the globe generally and southern Africa in particular have demonstrated an even greater responsibility to take care of our finite freshwater resources. This then means that the responsibility for water and the environment is a collective phenomenon not unique to southern Africa.
With reference to different parts of southern Africa, it cannot be denied that water is a vital commodity for many sectors of the economy. For instance, the agro-industrial, manufacturing, mining and domestic consumptive sectors are largely dependent on water. In the southern African literature on rural and urban settings, while water, sanitation and hygiene (WASH) need to be prioritised as a human right, not many scholars, notwithstanding several UN WHO reports (e.g. WHO 2015) and international scholars such as Lane (2008:323-331) and Brown et al. (2012:11-29), have written on this crucial sub-sector of water. Access to WASH includes safe water, adequate sanitation and hygiene education. Mainly WASH services provide for water availability and quality, the presence of sanitation facilities and availability of soap and water for hand washing.

In the world in which we live today, adequate water, sanitation and hygiene are essential components of providing basic health services to citizens. The provision of WASH in healthcare facilities serves to prevent infections and spread of disease, protect people and uphold the dignity of vulnerable populations, including pregnant women and the disabled. Many healthcare facilities in low-resource settings (lowincome countries) have no WASH services, severely compromising the ability to provide safe and people-centred care and presenting serious health risks to both healthcare providers (staff) and those seeking treatment (patients).

Contributing to the historiography on health and sanitation, Lane (2008) has brought up the debate of a dysfunctional world consisting of two halves: 'half have good sanitation, and half don't even have basic sanitation'. Hence, in the latter case, the accusation by Lane is that 'donors, governments and organizations have virtually orphaned sanitation by placing it as an add-on to water programmes'. Similarly, Brown et al. advocate committed or dedicated WASH interventions by suggesting that 'water, sanitation and hygiene interventions can interrupt diarrhoeal disease transmission and reduce the burden of morbidity and mortality associated with faecal-oral infections'. Conformity to WASH procedures can therefore reduce illness and death from such diseases afflicting some southern African countries like Zimbabwe as cholera, typhoid, dysentery, and also reduce poverty and improve socio-economic development. An analysis of rural water delivery as well as water supply and sanitation (WSS) infrastructure and its general condition in the cities is as essential as are more scholarly works on it. Since the last decade of the 20th century, a significant body of work has attempted to explore the importance of water in cities (see Nyandoro 2019a). In this study, the organic linkages between water supply and sanitation, environmentalism and urban development are emphasised. Several scholars have noted that WSS infrastructure is invisible, but represents a vital part of any well-working city. Many researchers refer to these systems as the 'Invisible City'.

With regard to South Africa in particular, water-related governance processes of the early 20th century continued to 
manifest themselves in the 21st century, thereby assisting water historians in distilling emergent long-term trends in the water sector that are major influences on contemporary water history. Evidently, at the end of the Thabo Mbeki presidency (1999-2008), the social, economic and political landscape of South Africa was subject to significant change. Seen against the backdrop of the water-energy-food (WEF) nexus security theory perspective that features prominently in Tempelhoff's (2018) study, the countrywide electricity outages in the first half of 2008 were a seminal manifestation of emergent 'panarchy' states of creative destruction and recovery in the infrastructural system feeding into the nexus of water, energy and food. The WEF nexus theory is an integrative approach towards the achievement of sustainable use and security of the three WEF nexus resources (waterenergy-food). By focusing on the WEF nexus, Tempelhoff (2018) has amply assessed to what extent the country (contemplated as a social ecological system) has been able to adapt resiliently to challenges and opportunities, specifically in matters related to the available water resources in South Africa. Apart from South Africa, Zimbabwe and Botswana have also been forced to contend with scarce or finite water resources. Water is a scarce commodity that is also linked to both unnatural and natural disasters ${ }^{12}$ such as water contamination and diseases on the one hand and droughts and floods on the other. Contaminated underground water resources that were an alternative source of supply given the scarcity of surface water were a major challenge for some regional countries, such as Zimbabwe, hence the frequent outbreaks of water-borne diseases, such as cholera, typhoid and dysentery. Pollution thus led to the aggravation of the acute water shortages besetting some countries of the region. Scarcity literature therefore exists among novel efforts by scholars to proffer longer-term solutions to the water shortages (water crises) that frequently plague southern Africa as a result of endemic climate change-induced droughts and disease. One solution proffered by conflict historiography is effective management of local water and transboundary sources in an effort to prevent water conflicts.

Water management, its evolution and the efficacy of the institutions that are responsible for the delivery and management of this critical and vulnerable natural resource to inform water policy and water sector reforms relevant to contemporary Botswana are emphasised by Nyandoro (in press). Nyandoro (in press) contends that in the colonial and post-colonial epochs, water conflicts continued to operate at an internal level, but at times they assumed a transboundary dimension. In his 2004 publication, Mbaiwa postulates that southern Africa faces prospects for violent struggles over water resources use among the Okavango River Basin (ORB) states, particularly those states that are affiliate members of the Okavango River Basin Commission (OKACOM), namely, Botswana, Angola and Namibia. Given

\footnotetext{
12.For another perspective on the deleterious impact of natural disasters see Gopalakrishnan (2013:250-271). This outstanding scholarly work focuses on the Gopalakrishnan (2013.250-271). This outstanding scholarly work focuses on the significant increase in the human and economic impacts of water disasters. The article and other sources attest to the colossal destructive potential of wate disasters, but very limited detailed research has been conducted on global wate disasters in general and southern Africa in particular.
}

the current and future water demands, ${ }^{13}$ there is therefore a need for formal institutional steps by global and regional actors to facilitate sustainable development, natural resources management and peaceful cooperation in the basin (Mbaiwa 2004). Contrary to trends in much of the literature, there is great scope for enhanced inter-state cooperation in the basin provided an integrated management plan for the entire basin is developed and each basin member state observes and respects international and regional conventions and treaties governing the use of transboundary water resources when designing national water development projects that require the use of such water. In Boelens, Getches and Guevara-Gil's (2010) view, water is not the subject of experts, but the source of power, conflicting interests and identity battles.

Throughout history, struggles over the control of water resources have existed, but they have not been so pronounced as to lead to serious foreign wars. Water and the environment in southern Africa may be regarded as a security issue considering that it can be a source of conflict between states. At the international level, the problems that are affecting the world can be analysed in this way. However, at the local southern African level, the following bottom-up water strategies and solutions to water problems may have greater appeal.

\section{Bottom-up historiography of water in southern Africa: 20th and 21st centuries}

Top-down approaches have been a common feature in southern Africa, and have dominated previous literature on water compared to bottom-up approaches mainly covered by international scholars such as Boelens et al. (2010) and critiqued by Ingram (2010:595-596).

Twentieth- and 21st-century scholarly works on bottom-up water sector approaches compared to top-down approaches have dominated recent literal narratives about the perceived beneficial effects of the former versus the detrimental effects on society of the latter. Like the works of Boelens et al. and Ingram, works by Mapira (2011:258-267), Nhapi, Siebel and Gijzen (2006:101-108) and Nyandoro (2019a) cover critical thematic issues such as water and wastewater management, liquid waste management, water governance, formal (topdown governance) and informal (bottom-up democracy) spaces in urban waterscapes. Other studies, for example, Merrey (2008:899-905) and Van Der Waldt (2015:35-50), emphasise city council and state intervention in the water sector to facilitate supply through provision of delivery infrastructure and subsidies, but do not emphasise the role communities, civic society, human rights groups and NGOs play as Boelens et al. (2010), Ingram (2010), Mapira (2011), Nhapi et al. (2006) and Nyandoro (2019a) do. Civil society groups help advance water rights perspectives. Policy

13.'Water demand" represents the 'volume of water needed for a given activity. If supply is unconstrained, water demand is equal to water withdrawal'. Oestigaard (2012:23) and UN Water (2009:98). 
formulation in the water sector can be focused on novel civic society ideals or ethical principles around which a new historiography can be constructed. Allowing civil society and other agencies to devise multiple strategies for defending and asserting indigenous and grass-roots control over water can play a complementary role to state legislative planning.

\section{Conclusion}

A review of the southern African literature about water and the environment produced since the 1990s shows that an assortment of historiographies depicts major trends, themes, debates and a wide array of topical indulgencies. As illustrated in the article, clear historiographical benchmarks have been set based on the water scarcity paradigm, the WEF security nexus theory and the linkages between water, the environment and society. For people who are interested in learning the main debates and arguments and the general trend of the literature, various interdisciplinary water and environment historiographies in southern Africa are invariably being shaped, albeit with changing interpretations over time.

These debates are being formed through topical issues whose major benchmark is the emergence of a historiography that popularises sustainable socio-economic, cultural and hydropolitical paradigms. On the whole, water and the environment constitute a vast field of study, and this article has basically addressed the common and different themes from the country examples that are reflective of the bigger southern African regional landscape and water historiography. There are clear lessons to be learnt by others (not only those who are familiar with southern Africa but also those who have familiarity with water history, albeit from a broad global perspective) from this analysis of the wide and pre-eminent literature on water and the environment. Water clearly provides unique foundations for the study of socio-economic, hydro-political and environmental development in the selected southern African countries, with obvious implications for the African continent as a whole. The works of scholars point to the major topics, themes and trends that have characterised the contemporary water and environmental situation in these southern African countries, especially since the 1990s. Overall, not much dedicated research has been conducted on water in these SADC states, emphasising various aspects of the water sector's history such as irrigation, municipal water supply, sanitation and waste management issues. Works dealing with histories or economic histories of human engagement with the water realm in southern Africa are sparse.

The foregoing, to a large extent, demonstrates that the existing historiography on southern Africa, emphasises a sectoral approach that, among other things, includes topics on water and agriculture; water and sanitation; water supply and demand; transboundary water; water and the environment; water and climate change; water conflicts; large dams, displacement and their environmental impact; water legislation in historical perspective; water and rural development; rural and urban aspects of water; and water and aridity. In other words, because the region is arid, scholarship tends to focus on particular issues - water shortage, irrigation, provisioning, policy history and health within a national framework. While this is useful, a more thematic perspective than currently exists could be embraced in an effort to understand crosscutting and common themes across the regional countries studied in this essay. A consideration of such themes as water and wastewater management (under different governance systems); changes in policy and the legal framework; the intersections of race, class and gender in historical perspectives; migration, settlement and production; religion, culture; science and technology, together with damming and irrigation, would add an interesting dimension to the historiography and study of water in southern Africa. Scholars can expand their frame of reference to include water systems. It should be noted, however, that this historiographical review is by no means exhaustive, but it opens avenues for further or new comparisons and analyses on water and the environment as crucial components of development in the region and elsewhere.

\section{Acknowledgements}

The author would like to thank Prof. Derek Catsam of the University of Texas of the Permian Basin (UTPB) for reading the drafts of this article and providing incisive commentary.

\section{Competing interests}

The author declares that he has no financial or personal relationships that may have inappropriately influenced him in presenting this article.

\section{Author's contributions}

I declare that I am the sole author of this research article.

\section{Ethical considerations}

This article followed all ethical standards for research without direct contact with human or animal subjects.

\section{Funding}

This research received no specific grant from any funding agency in the public, commercial or not-for-profit sectors.

\section{Data availability statement}

Data sharing is applicable to this article as new data were created or analysed in this study.

\section{Disclaimer}

The views and opinions expressed in this article are those of the author and do not necessarily reflect the official policy or position of any affiliated agency of the author. 


\section{References}

Attwell, R.I.G., 1970, 'Some effects of Lake Kariba on the ecology of a flood plain of the mid-Zambezi valley of Rhodesia', Biological Conservation 2(3), 189-196. https:// doi.org/10.1016/0006-3207(70)90106-0

Boelens, R., Getches, D. \& Guevara-Gil, A., (eds.), 2010, Out of the mainstream: Water rights, politics and identity, Earthscan, Washington, DC.

Brown, J., Cavill, S., Cumming, O. \& Jeandron, A., 2012, 'Water, sanitation, and hygiene in emergencies: Summary review and recommendations for further research', in emergencies: Summary
Waterlines 31(1/2), 11-29.

Cleophas, L.C., 1997, 'Socio-economic factors influencing sustainable water supply in Botswana', Geojournal 41(1), 43-53.

Coetzee, J.M., 1988, White writing: On the culture of letters in South Africa, Yale University Press, New Haven, CT.

Department of Water Affairs and Forestry (DWAF), 2006, A history of the first decade of water service delivery in South Africa 1994-2004: Meeting the millennium development goals, DWAF, Pretoria.

Emas, R., 2015, 'The concept of sustainable development: Definition and defining principles', Brief for GSDR 2015, United Nations, New York.

Fontein, J., 2008, 'The power of water: Landscape, water and the state in Southern and Eastern Africa: An introduction', Journal of Southern African Studies 34(4) and Eastern Africa: An introduction', Journal of Souther

Fontein, J., 2017, 'Damming the Zambezi: Light and power for which nation?' Journal of Southern African Studies 43(2), 425-432. https://doi.org/10.1080/03057070. 2017.1291161

Frank, A.G., 1967, Capitalism and underdevelopment in Latin America, Monthly Review Press, New York.

Ginster, M., Gouws, C., Gouws, C.M., Maki, H., Mathipa, R., Motloung, S., Nyandoro, M. \& Tempelhoff, J.W.N., 2010, 'Views on unlawful water abstractions along the Liebenbergsvlei River, South Africa', TD: The Journal for Transdisciplinary Research in Southern Africa 6(1), 1-24. https://doi.org/10.4102/td.v6i1.128

Global Water Partnership (GWP), 2011, What is IWRM? - GWP Central and Eastern Europe: Towards a water secure world, viewed 12 July 2011, from https://www. gwp.org/en/GWP-CEE/about/why/what-is-iwrm/.

Gopalakrishnan, C., 2013, 'Water and disasters: A review and analysis of policy aspects', International Journal of Water Resources Development 29(2), 250-271. https://doi.org/10.1080/07900627.2012.756133

Government of Rhodesia, 1975, Sabi-Limpopo Authority Act [chapter 156], Government Printers, Salisbury.

Hughes, D.M., 2010, Whiteness in Zimbabwe: Race, landscape, and the problem of belonging, Palgrave Macmillan, New York.

Ingram, H., 2010, 'Out of the mainstream: Water rights, politics and identity', Water Alternatives 3(3), 595-596.

International Conference of Water and the Environment (ICWE), 1992, 'The Dublin statement on water and sustainable development', viewed 22 May 2019, from http://www.wmo.int/pages/prog/hwrp/documents/english/icwedece.html.

Isaacman, A.F. \& Isaacman, B.S., 2013, Dams, displacement, and the delusion of development: Cahora Bassa and its legacies in Mozambique, 1965-2007, Ohio University Press, Athens.

Kujinga, K. \& Manzungu, E., 2004, 'Enduring contestations: Stakeholder strategic action in water resource management in the Save Catchment Area, Eastern Zimbabwe', Eastern Africa Social Science Research Review 20(1), 67-91. https:// doi.org/10.1353/eas.2004.0003

Lane, J., 2008, 'The great promise of the International Year of Sanitation: Private sector involvement at the local level', Waterlines 27(4), 323-331.

Lenton, R. \& Muller, M. (eds.), 2009, Integrated water resources management in practice: Better water management for development, Earthscan Publications, London.

Makgala, C.J., 2012, 'Provision of local services by tribal administrations in Bechuanaland Protectorate, 1900-1966', South African Historical Journal 64(4), 787-806. https://doi.org/10.1080/02582473.2012.661754

Manzungu, E., 2001, 'A lost opportunity: The case of the water reform debate in the fourth parliament of Zimbabwe', Zambezia XXVIII(1), 97-120. https://doi. org/10.4314/zjh.v28i1.6761

Manzungu, E., 2004, Water for all: Improving water resource governance in Southern Africa, natural resources group and sustainable agriculture and rural livelihoods programme, International Institute for Environment and Development (IIED), London.

Manzungu, E. \& Dzingirai, V., 2012, 'Towards empowered stakeholder participation in water resource management in Zimbabwe', Journal of Social Development in Africa 27(1), 85-109.

Mapira, J., 2011, 'Urban governance and mismanagement: An environmental crisis in Zimbabwe', Journal of Sustainable Development in Africa 13(6), 258-267.

Mbaiwa, J.E., 2004, 'Causes and possible solutions to water resource conflicts in the Okavango River Basin: The case of Angola, Namibia and Botswana', Physics and Chemistry of the Earth, Parts $A / B / C 29(15-18), 1319-1326$. https://doi. org/10.1016/j.pce.2004.09.015

Merrey, D.J., 2008, 'Is normative integrated water resources management implementable? Charting a practical course with lessons from Southern Africa' Physics and Chemistry of the Earth 33, 899-905. https://doi.org/10.1016/j. pce.2008.06.026

Moyana, H.V., 1984, The political economy of land in Zimbabwe, Mambo Press, Gweru.
Musemwa, M., 2010, "From "sunshine city" to a landscape of disaster: The politics of water, sanitation and disease in Harare, Zimbabwe, 1980-2009' Journal of Developing Societies 26(2), 165-206. https://doi.org/10.1177/ Journal of Developing

Musemwa, M., 2014, Water, history and politics in Zimbabwe: Bulawayo's struggles with the environment, 1894-2008, Africa World Press, Trenton.

National Archives of Zimbabwe Records Centre (hereafter) NAZ (RC), ARDA, Box 348063, Location R24.9.6.4F, File: ADA/POL/1 Part 1: Formation of ADA, ADA's Extract of Parliamentary Debates, s.a.

NAZ (RC), ARDA, Box 348063, Location R24.9.6.4F, File: ADA/POL/1 Part 1: Formation of ADA, 'Agricultural Development Authority Act/Sabi-Limpopo Authority Act', G.B. Thorpe for Secretary for Agriculture to Controller, Agricultural Development Authority, Causeway, Salisbury, 01 December, 1977.

Nhapi, I., Siebel, M.A. \& Gijzen, H.J., 2006, 'A proposal for managing wastewater in Harare, Zimbabwe', Water and Environment Journal 20(2), 101-108. https://doi. org/10.1111/j.1747-6593.2006.00018.x

Nyandoro, M., 2011, 'Historical overview of the cholera outbreak in Zimbabwe (20082009)', Journal for Contemporary History 36(1), 154-174.

Nyandoro, M., 2012, 'Zimbabwe's land struggles and land rights in historical perspective - The case of Gowe-Sanyati irrigation (1950-2000)', Historia 57(2), 298-349.

Nyandoro, M., 2013, 'Water resource management perspectives in Botswana: A contrast between the colonial and the post-colonial periods up to 2010', United Nations University-Institute for Natural Resources in Africa (UNU-INRA) Working Paper, 2, pp. 1-35.

Nyandoro, M., 2014, 'Large dams: Harmony or acrimony with environmental resource management paradigms in Zimbabwe and Lesotho', Special Issue on Water, Bhatter College Journal of Multidisciplinary Studies IV, 50-67.

Nyandoro, M., 2018, 'Water supply and management in post-independence Botswana: A state and corporate undertaking, 1966-2014', Special Issue, Botswana Notes \& Records Journal (BNR) 50, 97-111.

Nyandoro, M., 2019a, 'Citizen engagement circumvented: An analysis of liquid waste information/knowledge, control and environmental policy perspectives in Harare, Zimbabwe', Environment and History Journal, 25(4), 575-611.

Nyandoro, M., in press, 'Views on water resource governance in Botswana', Botswana Notes \& Records Journal (BNR).

Oestigaard, T., 2012, 'Water scarcity and food security along the Nile: Politics, population increase and climate change', Current African Issues 49, 1-94.

Pahl-Wostl, C., Jeffrey, P. \& Sendzimir, J., 2011, 'Adaptive and integrated management of water resources', in R.Q. Grafton \& K. Hussey (eds.), Water resources planning and management, pp. 292-310, Cambridge University Press, Cambridge.

Palmer, R.H., 1977, Land and racial domination in Rhodesia, Heinemann, London.

Pazvakavambwa, S., 2002, The process and dynamics of catchment management in Zimbabwe, Save Africa Trust Publications, Harare.

Peters, P.E., 1984, 'Struggles over water: Struggles over meaning: Cattle, water and the State in Botswana', Africa 54(3), 29-49. https://doi.org/10.2307/1160738

Peters, P.E., 1994, Dividing the commons: Politics, policy and culture in Botswana, University Press of Virginia, Charlottesville, VA.

Republic of South Africa (RSA), 1997, Water Services Act, No. 108, In Government Gazette, 390(18522), 12.19: 1-70.

Republic of South Africa (RSA), 1998, National Water Act, No. 36, in Government Gazette, 398(19182), 08.26: 1-152.

Roder, W., 1964, 'The division of land resources in Southern Rhodesia', Annals of the Association of American Geographers 54(1), 41-58. https://doi. org/10.1111/j.1467-8306.1964.tb00473.x

Roder, W., 1965, The Sabi valley irrigation projects, Department of Geography research paper, 99, University of Chicago Press, Chicago.

Rodney, W., 1973, How Europe underdeveloped Africa, Bogle-L'Ouverture Publications, London.

Southern Rhodesia, 1962, Report of the advisory committee on development of economic resources of Southern Rhodesia (The Phillips Report), Government Printers, Salisbury.

Steenkamp, P., 1991, “"Cinderella of the empire?": Development policy in Bechuanaland in the 1930s', Journal of Southern African Studies 17(2), 292-308. https://doi.org/10.1080/03057079108708279

Swatuk, L.A. \& Rahm, D., 2004, 'Integrating policy, disintegrating practice: Water resources management in Botswana', Physics and Chemistry of the Earth 29 1357-1364. https://doi.org/10.1016/j.pce.2004.09.011

Tempelhoff, J.W.N., 2003, The substance of ubiquity: Rand Water 1903-2003, Kleio Publishers, Vanderbijlpark.

Tempelhoff, J.W.N., 2005, 'The commodification of water in the arid and semi-arid parts of South Africa: A preliminary historical exploration', Historia 50(1), 123-146.

Tempelhoff, J.W.N., 2009, 'Leaving behind a "twisted soul": The 2008-9 cholera outbreak in South Africa', Journal for Contemporary History 34(3), 174-191.

Tempelhoff, J.W.N., 2017, 'The Water Act, no. 54 of 1956 and the first phase of apartheid in South Africa (1948-1960)', Water History 9(2), 189-213.

Tempelhoff, J.W.N., 2018, South Africa's water governance hydraulic mission (1912-2008) in a WEF nexus context, AOSIS, Durbanville, Cape Town.

Tempelhoff, J.W.N., Hoag, H., Ertsen, M., Arnold, E., Bender, M., Berry, K. et al., 2009, 'Where has the water come from? Water History 1(1), 1-8. 
Tlou, T. \& Campbell, A., 1997, History of Botswana, Macmillan, Gaborone.

Turton, A.R., 1999a, Water scarcity and social adaptive capacity: Towards an understanding of the social dynamics of managing water scarcity in developing countries, SOAS, London.

Turton, A.R., 1999b, Water and state sovereignty: The hydropolitical challenge for states in arid regions, SOAS, London.

Turton, A.R., 1999c, Water demand management (WDM): A case study from South Africa, MEWREW occasional paper 4, Water Issues Study Group, University of London, SOAS, London.

Turton, A., 2000, Water and sustainable development: A southern perspective, African Water Issues Research Unit, University of Pretoria, Pretoria.

Turton, A.R., 2001, 'Hydropolitics and security complex theory: An African perspective', 4th Pan-European international relations conference, University of Kent, Canterbury, pp. 11-26.

Turton, A.R. \& Ohlsson, L., 1999, Water scarcity and social stability: Towards a deeper understanding of key concepts needed to manage water scarcity in developing countries, School of Oriental and African Studies (SOAS), London.
Turton, A.R., Patrick, M.J. \& Rascher, J., 2008, 'Editorial: Setting the scene Hydropolitics and the Development of the South African Economy', International
Journal of Water Resources Development 24(3), 323-327. https://doi. Journal of Water Resources Dev

Turton, A.R. \& Warner, J.F., 2002, 'Exploring the population/water resources nexus in the developing world', Finding the Source: The Linkages between Population and Water, 52-81.

UN Water, 2009, The United Nations world water development report 3: Water in a changing world, UNESCO, Paris.

Van Der Waldt, G., 2015, 'Government interventionism and sustainable development The case of South Africa', African Journal of Public Affairs 8(3), 35-50.

White, C., 2013, Integrated water resources management: What is it and why is it used? URS, London, viewed 22 May 2019, from http://www.globalwaterforum. org/2013/06/10/integrated-water-resources-management-what-is-it-and-why-isit-used/.

World Health Organization (WHO), 2015, Water, sanitation and hygiene in health care facilities: Status in low and middle income countries and way forward, WHO \& UNICEF Report, WHO, Geneva. 